\title{
Mengganti Mikrokontroller Mesin Dust Collector pada PT. xxx dengan PLC OMRON CP1E- NA20CD-R
}

\author{
Surawan Setiyadi $1^{*}$ dan Edo Aulia Billy Fany ${ }^{1}$ \\ ${ }^{1}$ Study Program of Electrical Engineering, President University, Bekasi 17550, Indonesia \\ *Corresponding author: surawan@ president.ac.id
}

\begin{abstract}
As a result of the production of powder processing causes a lot of dust around the production machine and factory. This of course can cause pollution. Dust needs to be collected using a Dust Collector (DC) machine. The controller on the DC machine at PT. xxx is often damaged in the control unit and requires repairs at a cost of around $R p .5,000,000$ per unit. In facts there are about 10 units of machines at PT.xxx that must work all. Because of DC machines are often damaged in their controllers, the maintenance department made a development to make replacement DC machine controllers. Namely using the Programmable Logic Controller (PLC). This PLC replaces the microcontroller unit on the DC machine, PLC uses ladder diagram programming language that is easily understood by some people working in the world of control. PLC parts that are easily found in the market and programming languages that are easy to understand and reliability make one of the reasons this PLC is used to replace the microcontroller unit.
\end{abstract}

Keywords: DC, Ladder Diagram, PLC

\section{ABSTRAK}

Akibat produksi pengolahan bubuk banyak menimbulkan debu-debu di sekitar mesin produksi maupun pabrik. Hal ini tentunya dapat mengakibatkan polusi. Debu perlu dikumpulkan dengan menggunakan mesin Dust Collector (DC). Pengendali pada mesin DC pada PT. xxx seringkali rusak pada unit pengendalinya dan membutuhkan perbaikan dengan biaya sekitar Rp. 5.000.000 tiap unitnya. Padahal ada sekitar 10 unit mesin di PT.xxx yang harus bekerja semua. Oleh karena mesin DC seringkali rusak pada pengendalinya maka dari bagian perawatan membuat suatu pengembangan untuk membuat pengganti pengendali mesin DC. Yaitu menggunakan Programmable Logic Controller (PLC). PLC ini yang menggantikan unit pengendali pada mesin DC yaitu mikrokontroller. PLC menggunakan Bahasa pemrograman ladder diagram yang mudah dimengerti oleh sebagian orang yang berkecimpung di dunia kontrol. Suku cadang PLC yang mudah ditemui dan bahasa pemrograman yang mudah dimengerti dan kehandalan menjadikan salah satu alasan PLC ini digunakan untuk menggantikan unit pengendali mikrokontroller.

Kata Kunci: DC, Ladder Diagram, PLC

\section{Pendahuluan}

\section{A. Latar Belakang}

Mesin Dust Collector (DC) adalah mesin yang berfungsi mengumpulkan debu-debu di sekitar mesin akibat dari pengolahan material bubuk yang digunakan untuk produksi. Debu-debu tersebut harus dikumpulkan agar tidak menimbulkan polusi di seiktar pabrik. Mesin DC bertugas untuk mengumpulkan debu-debu tersebut. Pengumpulan debu pada mesin DC menggunakan filter yang bertugas sebagai penyaring debu-debu tersebut. Filter sebagai penyaring debu mempunyai lubang yang sangat kecil dalam ordo mikron. Karena bertugas sebagai penyaring dan mempunyai lubang, tidak menutup kemungkinan lubang pada filter tersebut mengalami hambatan. Jika hambatan semakin banyak maka fungsi filter menjadi tidak berfungsi.

Pengendali mesin DC mempunyai untuk membersihkan filter dengan cara membuka 5 buah solenoid valve secara bergantian. Selain itu tugas yang lain adalah untuk mengetahui kapan filter tersebut sudah mengalami hambatan. Pengendali mesin DC akan memberitahukan ke ruang pengendali utama yaitu ruang Distributed Controlled System (DCS) bahwa filter sudah saatnya untuk diganti.

Selain memberitahukan ke ruang DCS, pengendali tersebut juga mempunyai indikator tekanan yang ada di dalam mesin DC tersebut. Mesin DC ini menggunakan mikrokontroller sebagai pengendalinya.

PT. xxx di Cikarang mempunyai 10 mesin DC dengan 
pengendali mikrokontroller [1] dimana hampir setiap bulan pengendali mesin DC mengalami kerusakan. Kerusakan yang sering terjadi adalah di bagian power supply sehingga mesin DC tidak bisa membersihkan filter dan mendeteksi tekanan yang ada di dalam filter. Kerusakan pada pengendali mesin DC diperbaiki dengan sub-cont dengan pihak kedua. Biaya perbaikan untuk perbaikan pengendali tersebut kurang lebih Rp. 5.000.000, sedangkan harga barunya mencapai Rp. 28.000.000. Yang menjadi kendala adalah hampir setiap bulan pengendali mesin DC ini ada yang mengalami kerusakan. Jika diasumsikan satu bulan ada satu mesin yang rusak, maka dalam 10 bulan PT. xxx akan mengeluarkan biaya Rp. 50.000.000 untuk memperbaiki pengendali tersebut. Belum lagi jika pengendali tersebut harus menunggu suku cadang untuk mengganti komponen yang rusak. Sudah dipastikan akan menjadi kerugian dalam hal waktu karena mesin tersebut menjadi tidak bisa beroperasi karena menunggu suku cadang dan waktu perbaikan.

Dengan permasalahan ini bagian perawatan PT. Xxx mencari cara lain untuk mengganti alat pengendali mesin DC tersebut.

\section{B. Survey dan Analisa}

Dari survei dan analisa yang dilakukan didapatkan bahwa alat pengendalinya menggunakan mikrokontroller yang dibuat khusus untuk mesin DC. Sehingga jika terjadi kerusakan pada alat pengendali tersebut yang dilakukan oleh bagian perawatan adalah harus diperbaiki dan perbaikannya harus di sub-cont ke supplier yang menjual alat tersebut.

Alat tersebut terdiri satu modul yang didalamnya sudah menjadi satu kesatuan sistem kerja mesin DC. Diantaranya adalah masukan tekanan udara yang masuk ke sensor tekanan, sensor tekanan tersebut menjadi satu kesatuan di dalam modul tersebut. Tidak hanya sensor yang menjadi satu dengan modul tersebut, tampilan untuk menampilkan tekanan, keluaran informasi yang diteruskan ke ruang DCS dan 5 buah keluaran solenoid valve menjadi satu juga dalam satu modul. Gambar 1 menunjukkan Dust Collector modul yang menggunakan pengendali mikrokontroller.

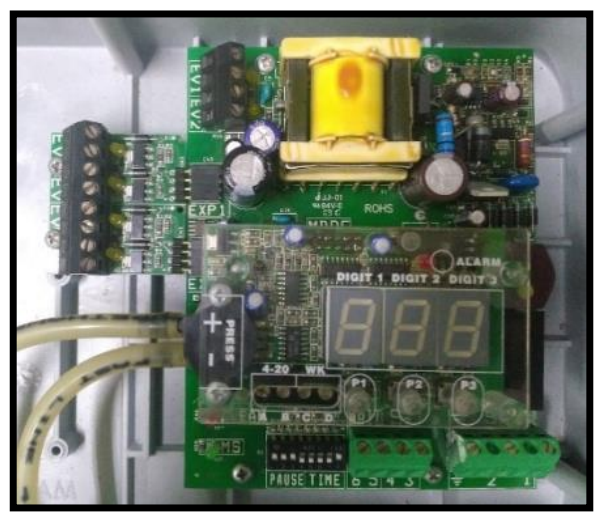

Gambar 1. Dust Controller Module Controller

Dari alat atau yang disebut sebagai modul yang terpasang saat ini memang mempunyai suatu keuntungan yaitu dalam satu modul sudah menjadi satu kesatuan alat yang bisa bekerja untuk mesin DC dan mempunyai dimensi yang ringkas kurang lebih 200 x 100 mm, mudah dalam pemasangan. Namun mempunyai kelemahan jika ada salah satu komponen yang rusak misalnya hanya sensornya saja atau relainya saja maka tidak serta merta bisa langsung diganti sensornya atau relainya akan tetapi harus mencopot modul tersebut dan dilakukan penggantian komponen. Penggantian komponen inipun juga memerlukan waktu untuk dilakukan perbaikannya sehingga tidak dengan cepat untuk memperbaiki mesin DC dan pada akhirnya mesin DC tidak bisa dioperasikan dan akan menggangu proses produksi.

Dari Analisa ini maka langkah selanjutnya adalah mencari alternatif lain untuk menggantikan modul tersebut dengan memperhatikan kemudahan mendapatkan suku cadang. Jika terjadi kerusakan akan lebih cepat dalam penanganannya sehingga tidak terlalu lama mengganggu kegiatan produksi dan dengan biaya yang lebih murah daripada membeli atau memperbaiki modul sebelumnya.

\section{DASAR TEORI}

\section{A. Programmable Logic Controller OMRON CPIE}

PLC dengan model SYSMAC CP1E merupakan PLC tipe package yang diproduksi oleh OMRON. PLC ini didesain untuk penaplikasian yang mudah. CP1E memiliki unit CPU model dasar, dengan tipe E••(S) blablabla untuk operasi kendali sederhana menggunakan dasar, pergerakan, aritmatika, serta instruksi perbandingan. Tipe ini juga memiliki unit CPU model aplikasi, dengan tipe N/NA ••(S•) yang mendukung koneksi ke Programmable Terminals, inverter, serta pengendali servo [2]. Unit CPU dengan tipe NA memiliki fungsi analog, dengan 2 masukkan analog untuk tegangan/arus serta 1 keluaran analog bawaan untuk teganga/arus [3]. PLC dapat dilihat pada Gambar 2.
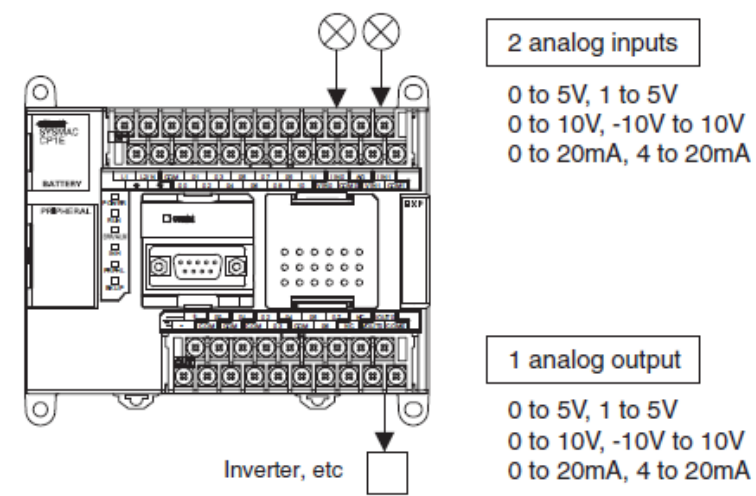

Gambar 2. Programmable Logic Controller CP1E [3]

\section{B. Sensor Tekanan PSAN}

Sensor tekanan digital seri PSAN tersedia dalam tipe kabel (hanya untuk jenis fluida) dan tipe konektor (jenis fluida dan pneumatik). Sensor ini mampu mengukur dan menampilkan berbagai jenis tekanan, seperti gas, cairan, dan juga minyak. Seri PSAN ini dilengkapi beberapa fungsi yang mudah digunakan seperti penyesuaian nilai nol, pemantauan nilai puncak, serta pencegahan gemertak. Keluaran dengan dua poin yang independen tersedia dengan opsi antara normally open serta normally closed 
[4]. Sensor tekanan yang dipakai pada penelitian ini dapat dilihat pada Gambar 3.

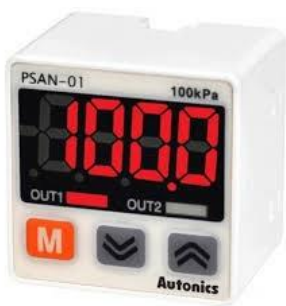

Gambar 3. Sensor Tekanan Seri PSAN [5]

Sensor ini memiliki beberapa spesifikasi yang dapat dilihat pada Tabel 1 .

Tabel 1. Spesifikasi Sensor Tekanan Seri PSAN [4]

\begin{tabular}{|c|c|}
\hline Parameter & Deskripsi \\
\hline Tipe Objek & Udara, Gas non-korosif. \\
\hline Arah Port Tekanan & Rear Fitting \\
\hline Tipe Koneksi & Konektor \\
\hline Panjang Kabel & Standar \\
\hline Jenis Tekanan & $12-24$ VDC $\pm 10 \%$ \\
\hline $\begin{array}{c}\text { Suplai Daya } \\
\text { Konsumsi Arus } \\
\text { Maksimum } \\
\text { (saat tipe tegangan) }\end{array}$ & $50 \mathrm{~mA}$ \\
\hline $\begin{array}{c}\text { Konsumsi Arus } \\
\text { Maksimum } \\
\text { (saat tipe arus) }\end{array}$ & \\
\hline $\begin{array}{c}\text { Struktur } \\
\text { Perlindungan }\end{array}$ & $75 \mathrm{~mA}$ \\
\hline
\end{tabular}

\section{DESAIN DAN IMPLEMENTASI}

Diagram blok rancangan mesin DC yang menggantikan mikrokontroller dapat dilihat pada Gambar 4 di bawah ini.

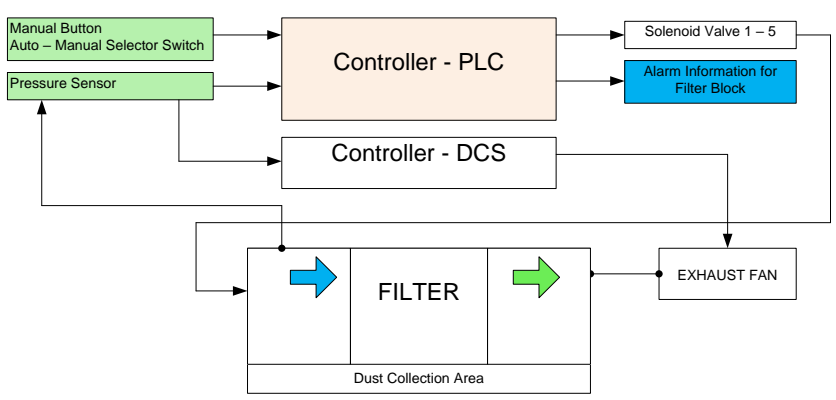

Gambar 4. Diagram Blok Instrumen

Pada diagram blok di atas dapat dilihat bahwa blok warna putih menggambarkan kondisi aslinya, alias tidak ada perubahan. Sedangkan di sisi lain, diagram blok yang mempunyai warna selain putih adalah adanya perubahan atau modifikasi yang dilakukan.

Sistem kerja diagram bloko di atas diterjemahkan ke dalam diagram alir pada Gambar 5.

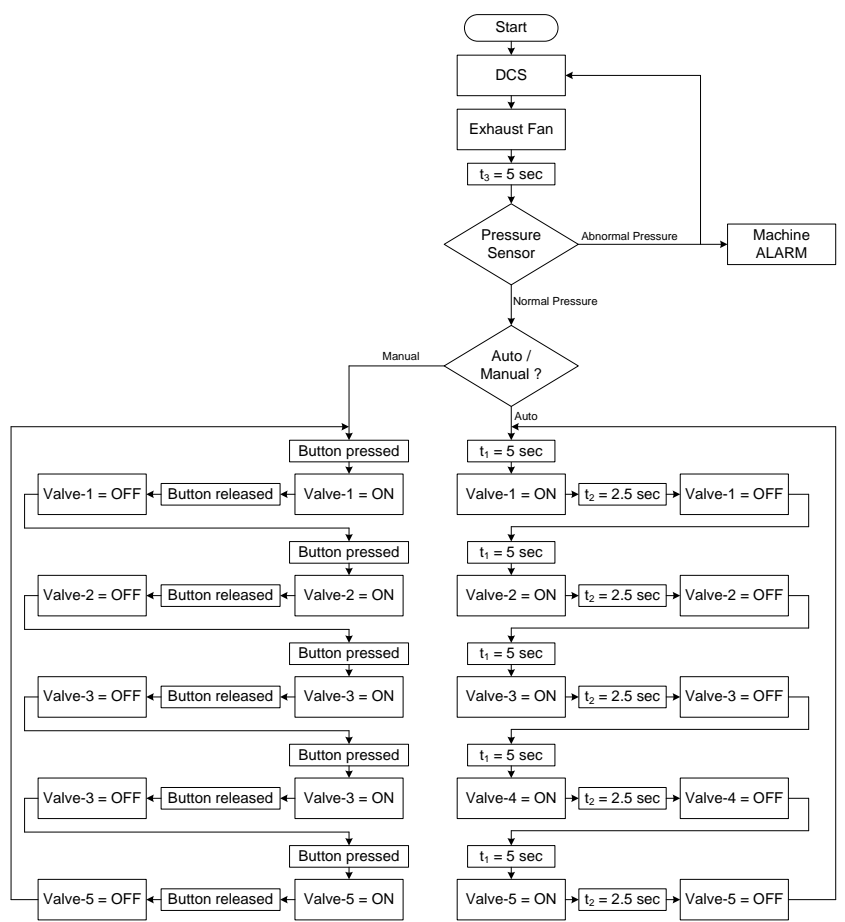

Gambar 5. Diagram Alir Sistem

Penjelasan blok diagram dan diagram alir di atas adalah sebagai berikut:

1. DCS menjalankan motor exhaust fan yang berfungsi sebagai pengumpul debu. Debu dari panah warna biru tersedot ke arah warna hijau yang disaring melalui filter. Debu yang terkumpul akan dimasukkan ke Dust Collector area.

2. Sensor tekanan berfungsi mendeteksi tekanan yang ada di area panah warna biru. Jika nilai tekanan pada area panah warna biru di bawah nilai pengaturan dan setelah waktu mencapai 5 detik tidak ada alarm maka kondisi filter mesin DC dapat dikatakan dalam kondisi bersih. Namun jika dalam waktu kurang dari 5 detik terjadi alarm maka kondisi filter mesin DC dalam kondisi kotor. Kemudian PLC akan memberikan informasi ke DCS selanjutnya pengendali mesin DC menghentikan sistem dan memberikan informasi alarm. Terjadinya alarm yang dikarenakan oleh kondisi filter yang kotor, sehingga sudah waktunya filter untuk diganti dengan yang baru.

3. Mesin DC memiliki selector switch yang berfungsi untuk memilih mode manual atau mode otomatis. Selain itu terdapat juga 5 (lima) buah solenoid valve yang bekerjanya secara bergantian berfungsi untuk membuat getaran di sekitar filter. Dengan adanya getaran di sekitar filter maka debu yang berada di area mesin DC akan dikumpulkan ke dalam area tempat dust collection area.

4. Untuk cara kerja mode manual adalah sebagai berikut:

a) Pada saat kondisi pressure sensor normal (normal pressure) dilanjutkan dengan menekan tombol maka valve-1 bekerja. 
Setelah tombol tidak ditekan maka valve1 tidak bekerja.

b) Kemudian menekan tombol lagi maka valve-2 bekerja. Setelah tombol tidak ditekan maka valve-2 tidak bekerja.

c) Demikian seterusnya sampai dengan valve-5 dan akan kembali ke valve-1.

5. Untuk cara kerja mode otomatis adalah sebagai berikut:

a) Pada saat kondisi sensor tekanan normal (normal pressure) 5 detik kemudian valve-1 bekerja. Setelah 2.5 detik valve-1 tidak bekerja.

b) Setelah 5 detik dari valve-1 tidak bekerja, valve-2 yang bekerja. Setelah 2.5 detik valve-2 tidak bekerja.

c) Demikian seterusnya sampai dengan valve-5 akan kembali ke valve-1.

Panel listrik bagian dalam PLC dapat dilihat pada Gambar 6 .

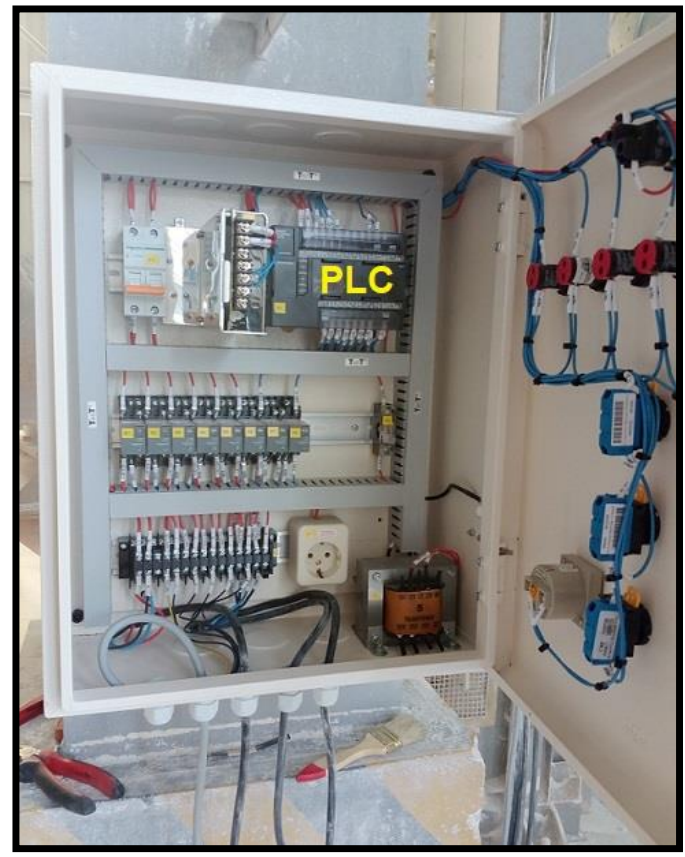

Gambar 6. Bagian Dalam Panel PLC yang Baru

Untuk panel listrik bagian luar dapat dilihat pada Gambar 7.

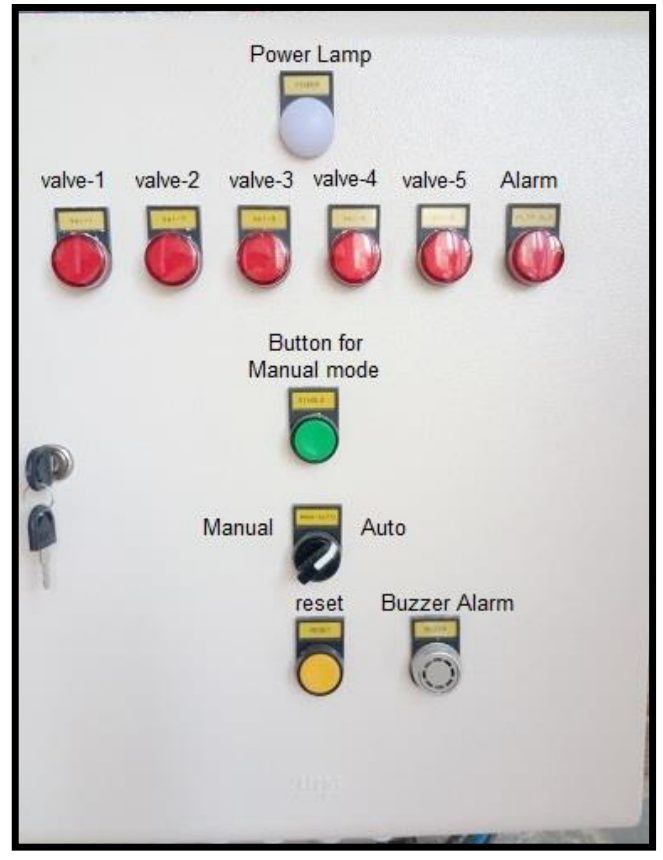

Gambar 7. Bagian Luar Panel PLC yang Baru

Sedangkan posisi solenoid valve dan dust collection area dapat dilihat pada Gambar 8 dan Gambar 9 di bawah ini.

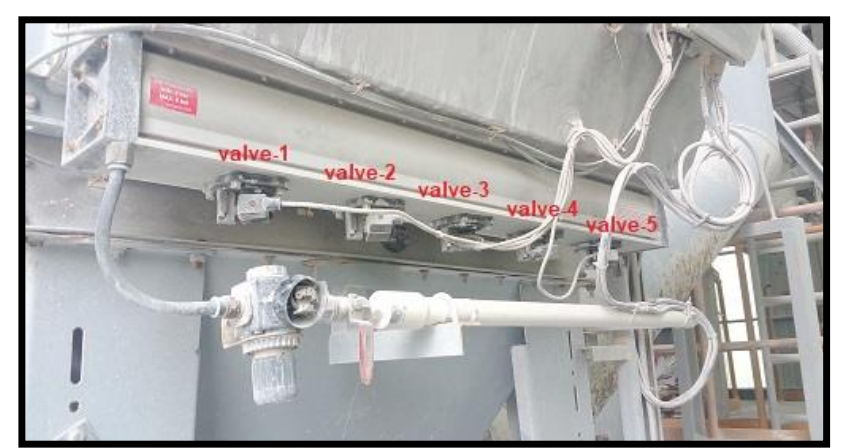

Gambar 8. Posisi Solenoid valve

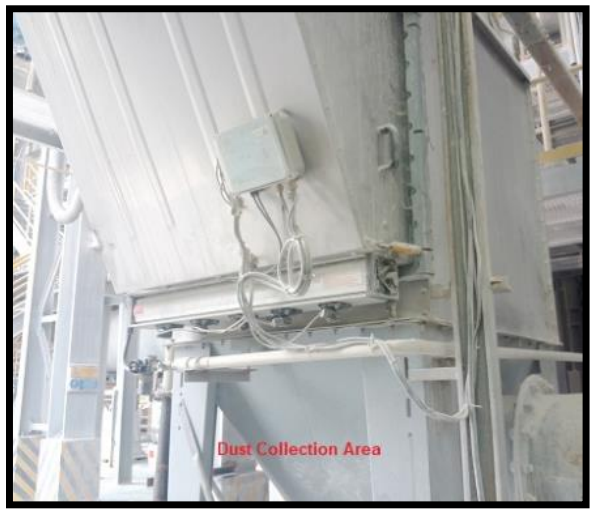

Gambar 9. Dust Collection Area

Posisi daripada daerah pendeteksian tekanan yang dimasukkan ke dalam sensor tekanan dapat dilihat pada Gambar 10. 


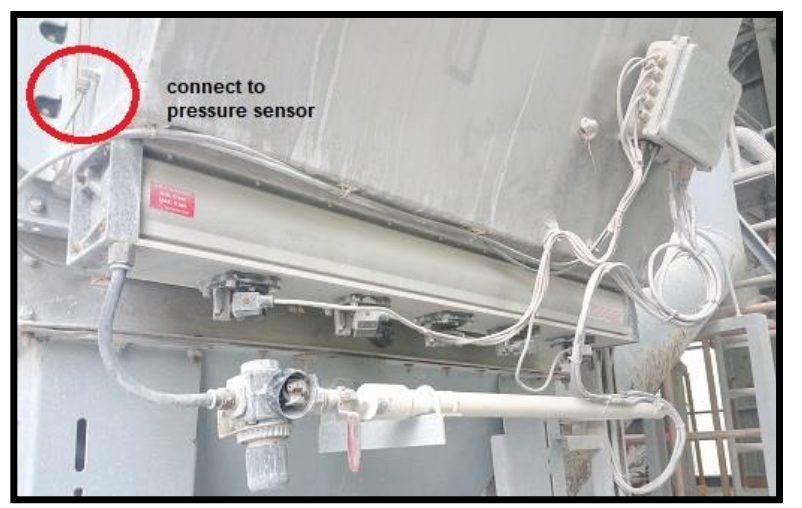

Gambar 10. Area Deteksi untuk Presure Sensor

Kondisi tekanan normal yang ditampilkan ke dalam sensor tekanan dapat dilihat pada Gambar 11, sedangkan kondisi tekanan tidak normal dapat dilihat pada Gambar 12.

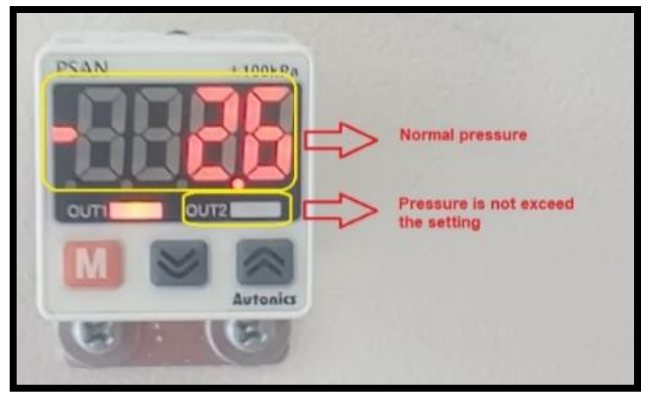

Gambar 11. Tekanan Normal

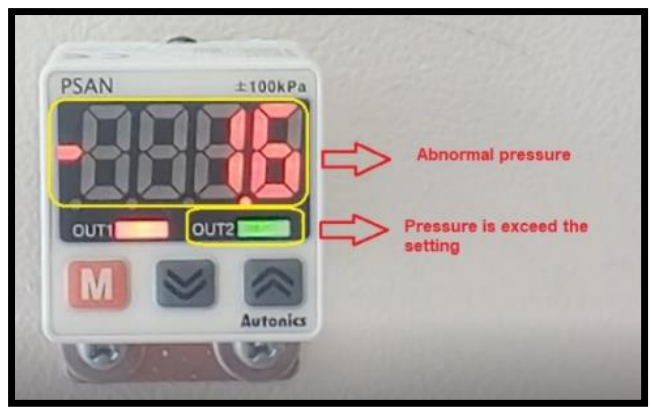

Gambar 12. Tekanan Tidak Normal

\section{PERCOBAAN INSTRUMEN}

Setelah dilakukan perakitan panel dan dilanjutkan dengan memasang panel ke mesin DC, kemudian dilakukan pengetesan. Pengetesan ini dilakukan dengan dua tahapan. Tahap pertama adalah pengetesan mode manual dan mode otomatis tanpa adanya alarm, dan tahap kedua adalah dengan alarm.

Untuk pengetesan alarm dilakukan dengan cara menghambat aliran yang masuk ke sensor tekanan.

\section{A. Tes Manual Tanpa Alarm}

Posisikan selector switch pada panel mesin pada posisi manual. Setelah DCS dihidupkan maka exhaust fan akan menyala dan sensor tekanan mendeteksi adanya tekanan di mesin DC dan 5 detik kemudian sistem siap bekerja. Ladder diagram pada PLC untuk pengoperasian mode manual dapat dilihat pada gambar 13 .

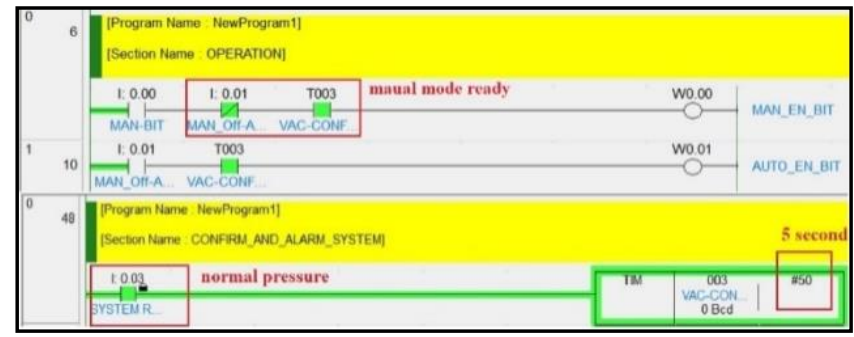

Gambar 13. Mode Operasi Manual

Percobaan pada manual mode dapat dilihat pada Tabel 2 berikut ini:

Tabel 2. Data Percobaan Mode Manual

\begin{tabular}{|c|c|c|c|c|c|c|}
\hline \multirow{2}{*}{$\begin{array}{l}\text { Kondisi } \\
\text { Tombol } \\
\text { Manual }\end{array}$} & \multirow{2}{*}{ Step - n } & \multicolumn{5}{|c|}{ Keluaran Valve } \\
\hline & & $\begin{array}{l}8 \\
8\end{array}$ & $\begin{array}{l}\overline{0} \\
\dot{8}\end{array}$ & 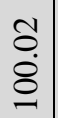 & $\begin{array}{l}\varrho \\
\varrho \\
\varnothing\end{array}$ & 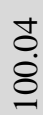 \\
\hline 0 & \multirow{2}{*}{1} & 0 & 0 & 0 & 0 & 0 \\
\hline 1 & & 1 & 0 & 0 & 0 & 0 \\
\hline 0 & \multirow{2}{*}{2} & 0 & 0 & 0 & 0 & 0 \\
\hline 1 & & 0 & 1 & 0 & 0 & 0 \\
\hline 0 & \multirow{2}{*}{3} & 0 & 0 & 0 & 0 & 0 \\
\hline 1 & & 0 & 0 & 1 & 0 & 0 \\
\hline 0 & \multirow{2}{*}{4} & 0 & 0 & 0 & 0 & 0 \\
\hline 1 & & 0 & 0 & 0 & 1 & 0 \\
\hline 0 & \multirow{2}{*}{5} & 0 & 0 & 0 & 0 & 0 \\
\hline 1 & & 0 & 0 & 0 & 0 & 1 \\
\hline
\end{tabular}

Dari tabel 1 di atas dapat dilihat pada diagram ladder PLC untuk step ke 1, step ke 2 step ke 3, step ke 4 dan step ke 5. Untuk ladder diagram tersebut hanya ditampilkan untuk step 1, 2, dan 5 pada Gambar $(14-16)$. Sedangkan step ke 3 dan ke 4 adalah urutan setelah step ke 3 .

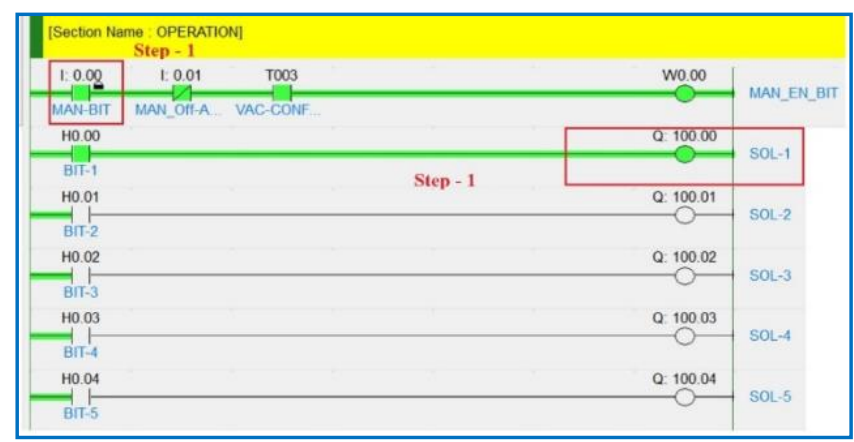

Gambar 14. Step Pertama pada Mode Manual 


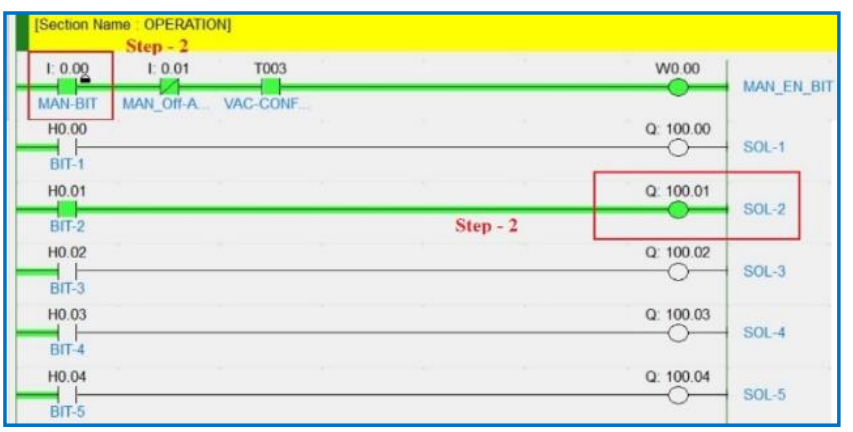

Gambar 15. Step Kedua pada Mode Manual

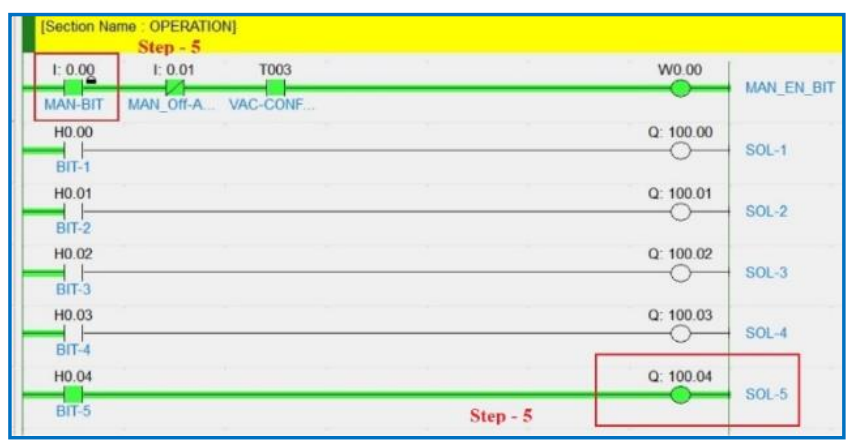

Gambar 16. Step Kelima pada Mode Manual

\section{B. Tes Otomatis Tanpa Alarm}

Selector switch pada panel mesin pada posisi otomatis. Setelah DCS dihidupkan maka exhaust fan akan menyala dan sensor tekanan mendeteksi adanya tekanan di mesin DC dan 5 detik kemudian sistem siap bekerja. Solenoid valve akan bekerja bergantian dari valve-1 sampai dengan valve -5 secara otomatis. Diagram ladder dapat dilihat pada Gambar 17.

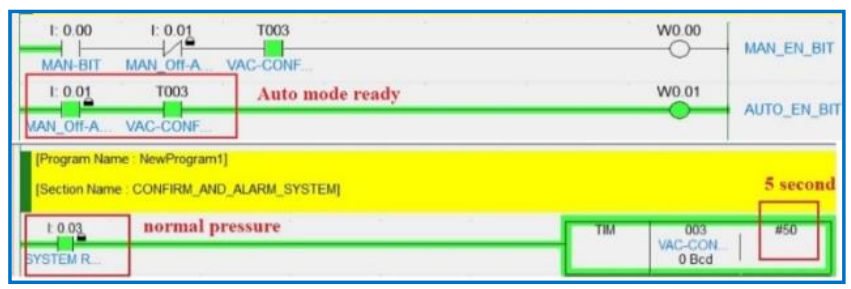

Gambar 17. Operasi Mode Otomatis

Percobaan pada mode otomatis dapat dilihat pada Tabel 3 di bawah ini.

Dari Tabel 2, dapat dilihat pada diagram ladder PLC untuk step ke 1 akan ON setelah waktu T0 tercapai, kemudian dilanjutkan mengaktifkan waktu $\mathrm{T} 1$, setelah waktu T1 tercapai maka step ke 1 akan OFF dan waktu T0 menjadi OFF dan dilanjutkan ke step ke 2 dan waktu T1 akan OFF. Step ke 2 akan ON setelah waktu T0 tercapai, setelah waktu T1 tercapai maka step ke 2 akan OFF demikian seterusnya sampai step yang ke 5 akan kembali lagi ke step yang ke 1 . Selanjutnya, sistem akan bekerja secara otomatis dari step ke 1 sampai ke 5, dan akan kembali lagi ke step ke 1 . Untuk gambar step ke 1 sampai dengan step ke 2 dapat dilihat pada Gambar $(18-21)$.
Tabel 3. Data Percobaan Mode Otomatis

\begin{tabular}{|c|c|c|c|c|c|c|}
\hline \multirow{2}{*}{$\begin{array}{l}\text { Urutan } \\
\text { Timer }\end{array}$} & \multirow{2}{*}{ Step - $n$} & \multicolumn{5}{|c|}{ Keluaran Valve } \\
\hline & & $\begin{array}{l}8 \\
8 \\
\dot{8}\end{array}$ & $\begin{array}{l}\overline{0} \\
\dot{8}\end{array}$ & $\begin{array}{l}\delta \\
\delta \\
8\end{array}$ & $\begin{array}{l}0 \\
\dot{8} \\
8\end{array}$ & $\begin{array}{l}+ \\
\stackrel{8}{8} \\
0\end{array}$ \\
\hline $\mathrm{T} 0=\mathrm{ON}$ & \multirow{2}{*}{1} & 1 & 0 & 0 & 0 & 0 \\
\hline $\begin{array}{c}\mathrm{T} 1=\mathrm{ON} \\
\text { satu siklus }\end{array}$ & & 0 & 0 & 0 & 0 & 0 \\
\hline $\mathrm{T} 0=\mathrm{ON}$ & \multirow{2}{*}{2} & 0 & 1 & 0 & 0 & 0 \\
\hline $\begin{array}{c}\mathrm{T} 1=\mathrm{ON} \\
\text { satu siklus }\end{array}$ & & 0 & 0 & 0 & 0 & 0 \\
\hline $\mathrm{T} 0=\mathrm{ON}$ & \multirow{2}{*}{3} & 0 & 0 & 1 & 0 & 0 \\
\hline $\begin{array}{c}\mathrm{T} 1=\mathrm{ON} \\
\text { satu siklus }\end{array}$ & & 0 & 0 & 0 & 0 & 0 \\
\hline $\mathrm{T} 0=\mathrm{ON}$ & \multirow{2}{*}{4} & 0 & 0 & 0 & 1 & 0 \\
\hline $\begin{array}{l}\mathrm{T} 1=\mathrm{ON} \\
\text { satu siklu }\end{array}$ & & 0 & 0 & 0 & 0 & 0 \\
\hline $\mathrm{T} 0=\mathrm{ON}$ & \multirow[b]{2}{*}{5} & 0 & 0 & 0 & 0 & 1 \\
\hline $\begin{array}{c}\mathrm{T} 1=\mathrm{ON} \\
\text { satu siklus }\end{array}$ & & 0 & 0 & 0 & 0 & 0 \\
\hline
\end{tabular}

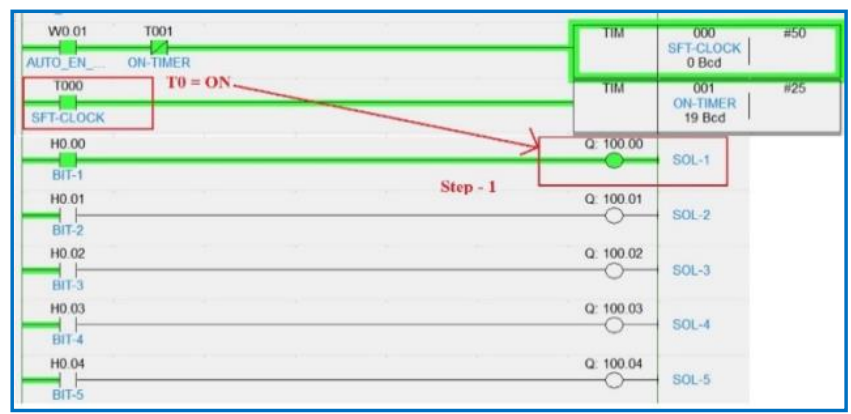

Gambar 18. Step Pertama pada Mode Otomatis, $\mathbf{T 0}=\mathbf{O N}$

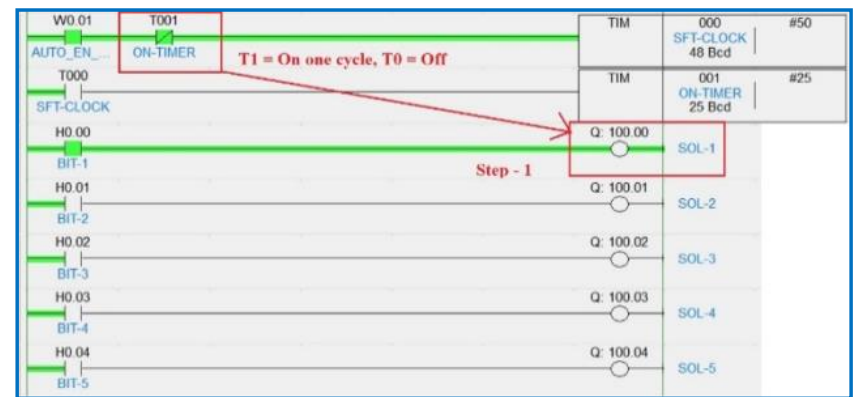

Gambar 19. Step Pertama pada Mode Otomatis, $\mathrm{T1}=\mathrm{ON}$ 


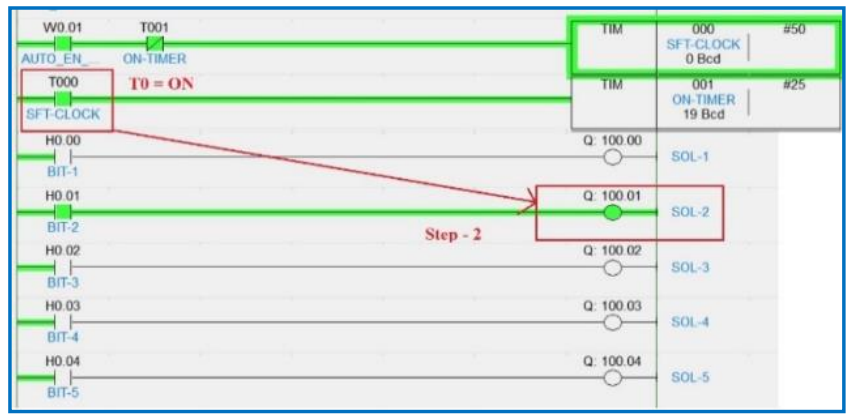

Gambar 20. Step Kedua pada Mode Otomatis, T0 = ON

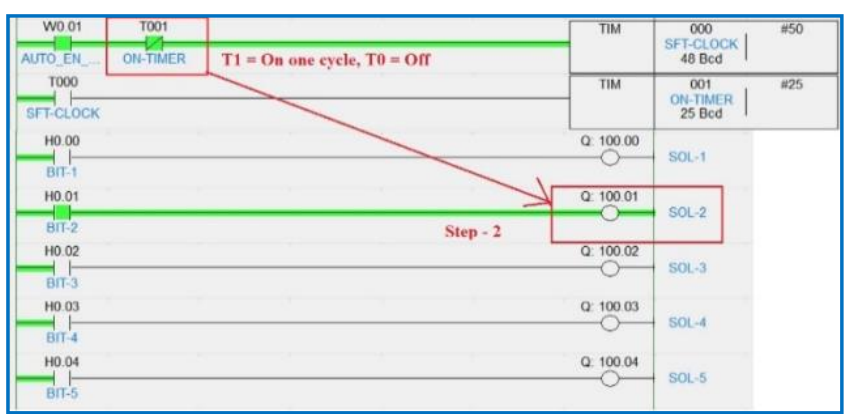

Gambar 21. Step Kedua pada Mode Otomatis, T1 = ON

\section{Tes Manual dan Otomatis Dengan Alarm}

Untuk pengetesan alarm, mode bisa dalam kondisi baik manual maupun otomatis. Karena kondisi alarm tidak berpatokan pada mode manual maupun mode otomatis. Pada saat tekanan di dalam mesin DC normal maka lampu indikator pada sensor tekanan (out2) pada gambar 11 tidak menyala. Diagram ladder pada PLC dapat dilihat pada Ggambar 22.

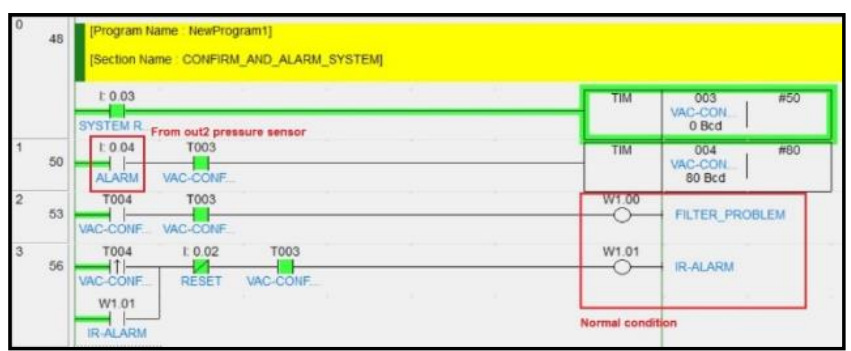

Gambar 22. Mesin DC pada Kondisi Normal

Pada saat tekanan di dalam mesin DC tidak normal maka lampu indikator pada sensor tekanan (out2) pada Gambar 12 menyala. Diagram ladder pada PLC dapat dilihat pada Gambar 23.

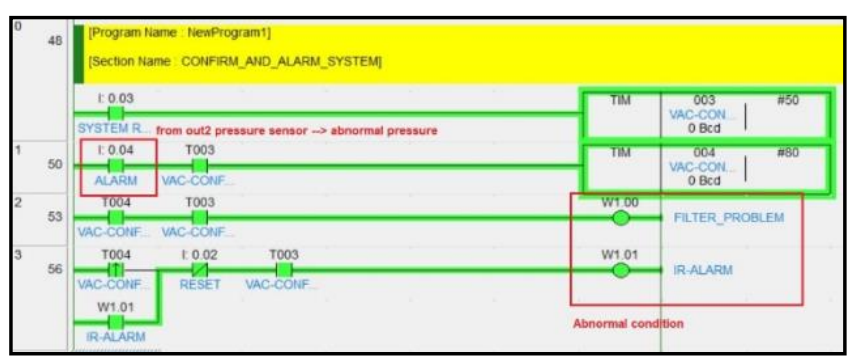

Gambar 23. Mesin DC pada Kondisi Tidak Normal

Dalam kondisi tidak normal ini sistem akan memberikan informasi lampu alarm menyala dan buzzer berbunyi. Untuk posisi lampu alarm dan buzzer pada panel seperti terlihat pada Gambar 24.

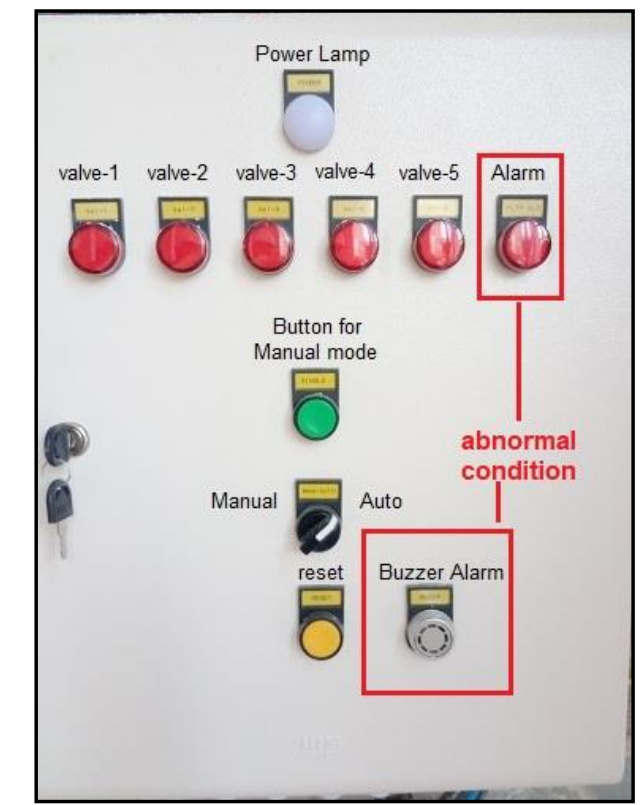

Gambar 24. Indikator Kondisi Tidak Normal pada Panel

Selain informasi alarm yang ada di panel listrik, maka sensor tekanan juga memberikan informasi ke panel DCS. Untuk pengkawatan dari sensor tekanan ke panel DCS dapat dilihat pada gambar listrik di Gambar 25.

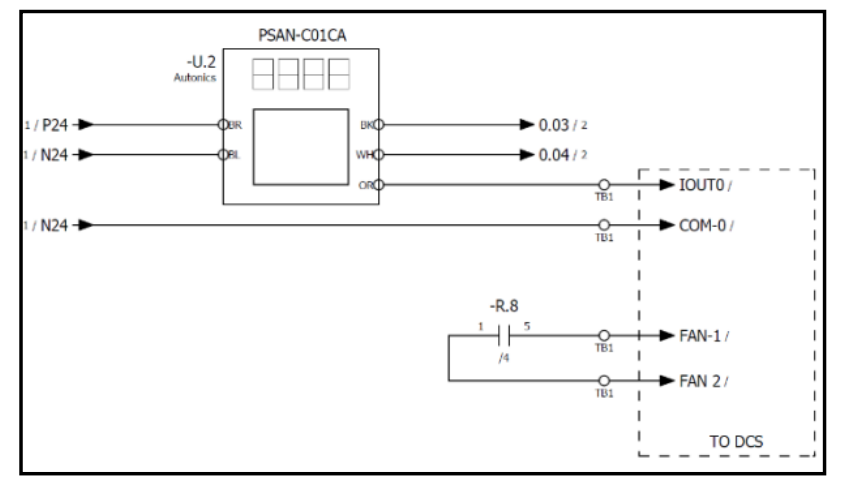

Gambar 25. Wiring Diagram dari Sensor Tekanan ke DCS

\section{KESIMPULAN DAN SARAN}

Beberapa poin yang menyimpulkan hasil penelitian ini adalah:

1. Pengendali mesin DC yang awalnya menggunakan mikrokontroller dapat digantikan dengan pengendali yang lain, yaitu PLC.

2. Penggantian pengendali dengan PLC dapat menghemat biaya perawatan yaitu Rp. 5.000.000 setiap bulannya, karena biaya yang dibutuhkan untuk penggantian pengendali dengan PLC hanya sebesar Rp. 10.000.000 untuk satu mesin.

3. Semenjak bulan Maret 2019 sampai dengan saat ini, penggantian dengan PLC ini belum mengalami kerusakan seperti pada saat penggunaan dengan mikrokontroller.

4. Jumlah solenoid valve untuk membersihkan filter dapat ditambah lagi agar sesuai dengan kebutuhan. 
Beberapa poin saran yang diajukan penulis adalah:

1. Mesin DC yang dimiliki oleh PT. Xxx adalah 10 mesin, dan disarankan untuk mengganti pengendali 9 mesin DC lainnya dengan PLC juga.

2. Penggunaan solenoid valve untuk membersihkan filter dapat mencapai 16 buah dengan cara menggantikan alamat bit.

\section{DAfTar Pustaka}

[1] Dust Collector User Manual

[1] OMRON User's Manual, CPIE Unit Hardware Sysmac CP Series, p30, 2016

[2] OMRON User's Manual, CP1E Unit Hardware Sysmac CP Series, p35, 2016

[3] Autonics, Spesifikasi Sensor Tekanan PSAN [Online]. Tersedia: https://www.autonics.com/model/A1900000121. (Diakses: 27 Mei 2019)

[4] Autonics, Sensor Tekanan PSAN [Online]. Tersedia: https://www.autonics.com/series/3000473. (Diakses: 27 Mei 2019) 